\title{
The biomechanics of the bone and of metal, Zantex and PEEK bars in normal and osteoporotic condition, surrounding implants over protocols: an analysis by the
}

\section{Finite Element Method}

\author{
Biomecânica óssea, em condição normal e osteoporótica, circundante a implantes sob protocolos, e \\ das barras em metal, Zantex e PEEK: uma análise pelo Método de Elementos Finitos
}

Biomecánica ósea, en condiciones normales y osteoporóticas, implantes circundantes bajo

protocolos, y barras de metal, Zantex y PEEK: un análisis por el método de los elementos finitos

Received: 01/26/2022 | Reviewed: 02/03/2022 | Accept: 02/04/2022 | Published: 02/06/2022

\author{
Aline Batista Gonçalves Franco \\ ORCID: https://orcid.org/0000-0002-8793-0459 \\ Faculdade São Leopoldo Mandic, Brazil \\ E-mail: alinebgfranco@yahoo.com \\ Geraldo Alberto Pinheiro de Carvalho \\ ORCID: https://orcid.org/0000-0002-6279-3558 \\ Faculdade São Leopoldo Mandic, Brazil \\ E-mail: cdgeraldo@yahoo.com.br \\ Amanda Gonçalves Franco \\ ORCID: https://orcid.org/0000-0003-0983-7539 \\ Universidade de Itaúna, Brazil \\ E-mail: amandagfranco38@gmail.com \\ Juliana Trindade Clemente Napimoga \\ ORCID: https://orcid.org/0000-0003-1068-3039 \\ Faculdade São Leopoldo Mandic, Brazil \\ E-mail: juliana.napimoga@ slmandic.edu.br \\ Marcelo Henrique Napimoga \\ ORCID: https://orcid.org/0000-0003-4472-365X \\ Faculdade São Leopoldo Mandic, Brazil \\ E-mail: marcelo.napimoga@ slmandic.edu.br \\ Carlos Eduardo da Silveira Bueno \\ ORCID: https://orcid.org/0000-0002-2675-0884 \\ Faculdade São Leopoldo Mandic, Brazil \\ E-mail: carlosesbueno@terra.com.br \\ Flávia Lucisano Botelho do Amaral \\ ORCID: https://orcid.org/0000-0002-8934-6678 \\ Faculdade São Leopoldo Mandic, Brazil \\ E-mail: flbamaral@gmail.com
}

\begin{abstract}
This study aims to assess the biomechanical behavior of the alveolar bone surrounding the implants over protocol with metal, Polyether ether ketone (PEEK) and Zantex bars, in normal and osteoporotic conditions. For the simulation, geometric models of the mandibular arch were designed containing 5 implants and two variables. The first variable is the bone condition - normal and osteoporotic-, and the second is the material used in the protocol bars - metal, PEEK and Zantex. Simulation was performed using the Finite Elements Method. Results showed that the largest load peaks were concentrated in the medullary bone, both in the normal and osteoporotic conditions. The osteoporotic bone was subjected to more loads than the normal bone in all simulated structures. PEEK and Zantex bars are generally effective load dissipators, showing better performance than $\mathrm{Ni}-\mathrm{Cr}$ in both types of bone. It is important to assess the bone condition and its relationship with the material used in protocol-type prostheses infrastructure.
\end{abstract}

Keywords: Osteoporosis; Dental prosthesis; Finite element analysis.

\section{Resumo}

O objetivo deste trabalho foi avaliar o comportamento biomecânico do osso alveolar, nas condições normal e osteoporótica, circundante a implantes sob protocolo, com barras em metal, Poliéter-éter-cetona (PEEK) e Zantex. Para a simulação foram construídos modelos geométricos de arco mandibular contendo 5 implantes com duas variáveis. A primeira foi a presença de osso normal e osteoporótico, e a segunda o material na confecção das barras de protocolo, metal, PEEK e Zantex. A simulação foi realizada pelo Método de Elementos Finitos. Os resultados mostraram que os 
maiores picos de carga foram concentrados no osso medular, tanto normal quanto osteoporótico. O osso osteoporótico recebeu mais cargas que o osso normal todas as estruturas simuladas. As barras em PEEK e Zantex se mostraram em geral elementos dissipadores de tensões efetivos, com uma dissipação de forças maior que Ni-Cr em ambos os tipos de ossos. Conclui-se a importância da avaliação condição óssea e sua relação entre o material utilizado em infraestrutura de próteses tipo protocolo.

Palavras-chave: Osteoporose; Prótese dentária; Análise de elementos finitos.

\begin{abstract}
Resumen
El objetivo de este trabajo fue evaluar el comportamiento biomecánico del hueso alveolar, en condiciones normales y osteoporóticas, rodeando implantes bajo protocolo, con barras metálicas, Poliéter-éter-cetona (PEEK) y Zantex. Para la simulación se construyeron modelos geométricos del arco mandibular que contenían 5 implantes con dos variables. El primero fue la presencia de hueso normal y osteoporótico, y el segundo fue el material utilizado para fabricar las barras de protocolo, metal, PEEK y Zantex. La simulación se realizó por el Método de Elementos Finitos. Los resultados mostraron que los picos de carga más altos se concentraron en el hueso medular, tanto normal como osteoporótico. El hueso osteoporótico recibió más cargas que el hueso normal para todas las estructuras simuladas. Las barras de PEEK y Zantex demostraron ser elementos disipadores de estrés efectivos en general, con una disipación de fuerza mayor que el Ni-Cr en ambos tipos de huesos. Se concluye la importancia de evaluar el estado óseo y su relación entre el material utilizado en la infraestructura protésica tipo protocolo.
\end{abstract}

Palabras clave: Osteoporosis; Protesis dental; Analyse des éléments finis.

\title{
1. Introduction
}

Metal alloys are used in protocol-type prostheses for years but still show some constraints (Campbell et al., 2017). Among these are the high elasticity module - different from the bone's - and hardness, causing the improper distribution of load throughout the implants and support structures (Manolea et al., 2017). Therefore, metal-free alternatives, such as novel polymer material, have been increasingly studied to this end.

Polyether ether ketone (PEEK) has shown excellent physical and chemical properties (Najeeb et al., 2015; Bechir et al., 2016) and elasticity module closer to the bone's (Schwitalla et al., 2015).

Zantex, a novel material in the market, has captured the attention of the scientific community. Composed of a polymer matrix reinforced with a dense tridimensional network of glass fibers, it is biocompatible, and presents low elasticity module and low flexural strength (Biofunctional Materials - EUA). When used as partial fixed prosthesis infrastructure, presents higher fracture strength (Bergamo et al., 2019).

It is important to consider the bone condition when choosing novel materials. Osteoporosis causes an imbalance between neoformation and bone resorption, diminishing the bone's mineral density (Chaim et al., 2016). Its effects on the mouth are little understood (Rodrigues et al., 2014), hence the need for further studies to better guide the surgeon's decisions when caring for such patients.

The Finite Elements Methods was used to analyze and correlate the biomechanical behavior of the alveolar bone surrounding the implants over metal, PEEK and Zantek protocol bars in the presence of healthy and osteoporotic bones, under physiological occlusion condition.

The hypothesis of the study suggests that the behavior of the alveolar bone is similar in the two bone conditions, as well as for the three materials used as a protocol bar). Or that any of these conditions stand out over others.

\section{Methods}

Geometric objects representing the actual research object were simulated. Lower complete denture and mandible models (Nacional Ossos, Jaú, São Paulo, Brazil) were scanned using a 3D laser scanner (Nextengine HD, Santa Monica, USA). Then, 16 sweeps were performed in a circular fashion, at $22.5^{\circ}$ intervals, for each model. For the modeling of the edentulous mandible and the complete denture, a virtual model of the mandible from the geometry bank of the Nucleus of Three-Dimensional 
Technologies (NT3D) of the Renato Archer Campinas Information Technology Center (CTI Renato Archer) was used. The geometric changes were made using CAD Rhinoceros 7.0 (Mcneel \& Associates, USA). The tridimensional models consisted of edentulous mandibular arches with 5 Titamax CM ExAcqua-standard implants 3.75x11mm (Neodent) and CM mini straight abutments with $1.5 \mathrm{~mm}$ cuffs. The bars are designed with rectangular cross section measuring $4.0 \mathrm{~mm}$ of width $\mathrm{x} 6.0 \mathrm{~mm}$ of height and distal cantilever of $9.0 \mathrm{~mm}$ (Carvalho et al., 2017).

The normal medullary and cortical bones were type III-standard and defined with a $2 \mathrm{~mm}$ thickness (Lekholm et al. 1985). To simulate the osteoporotic bone, a normal bone model was reduced in 30\%, thus shifting from a $2 \mathrm{~mm}$ thickness to 1.4 mm, to represent advanced osteoporosis (Helgason et al., 2008; Kribbs, 1990).

The bar lining and the stock teeth were simulated in acrylic resin.

The models for each clinical condition are summarized below:

Model 1 (M1 - control): Mandibular arch containing 5 implants surrounded by normal bone and metallic protocol bar;

Model 2 (M2): mandibular arch containing 5 implants surrounded by osteoporotic bone and metallic protocol bar;

Model 3 (M3): mandibular arch containing 5 implants surrounded by normal bone and PEEK protocol bar;

Model 4 (M4): mandibular arch containing 5 implants surrounded by osteoporotic bone and PEEK protocol bar;

Model 5 (M5): mandibular arch containing 5 implants surrounded by normal bone and Zantex protocol bar;

Model 6 (M6): mandibular arch containing 5 implants surrounded by osteoporotic bone and Zantex protocol bar.

The models created were exported to the software Hypermesh (Altair, version 2019) for simulation.

The generated models were exported in STEP format to the Hypermesh software (Altair, version 2019).

For processing the mesh, which was generated with quadratic tetrahedral elements of 10 nodes (solid 187). All structures will be considered isotropic, homogeneous and linearly elastic and the contacts between the structures will be considered as perfect union.

Normal masticatory forces were simulated using axial and oblique loads of 100N (Craig, 1985).

Results were logged, analyzed and compared numerically and graphically.

\section{Results}

Shifts are given in millimeters (mm) and stress is given in Mega Pascal (Mpa).

\section{Axial loads}

The cortical bone was not subject to a large incidence of axial loads. Furthermore, the osteoporotic cortical bone showed similar behavior for all three materials: Ni-Cr, PEEK, and Zantex. In the normal bone, PEEK and Zantex are more effective elements of stress dissipation (Figure 1 and Table 1). 
Figure 1: Axial load cortical bone stress (Mpa).
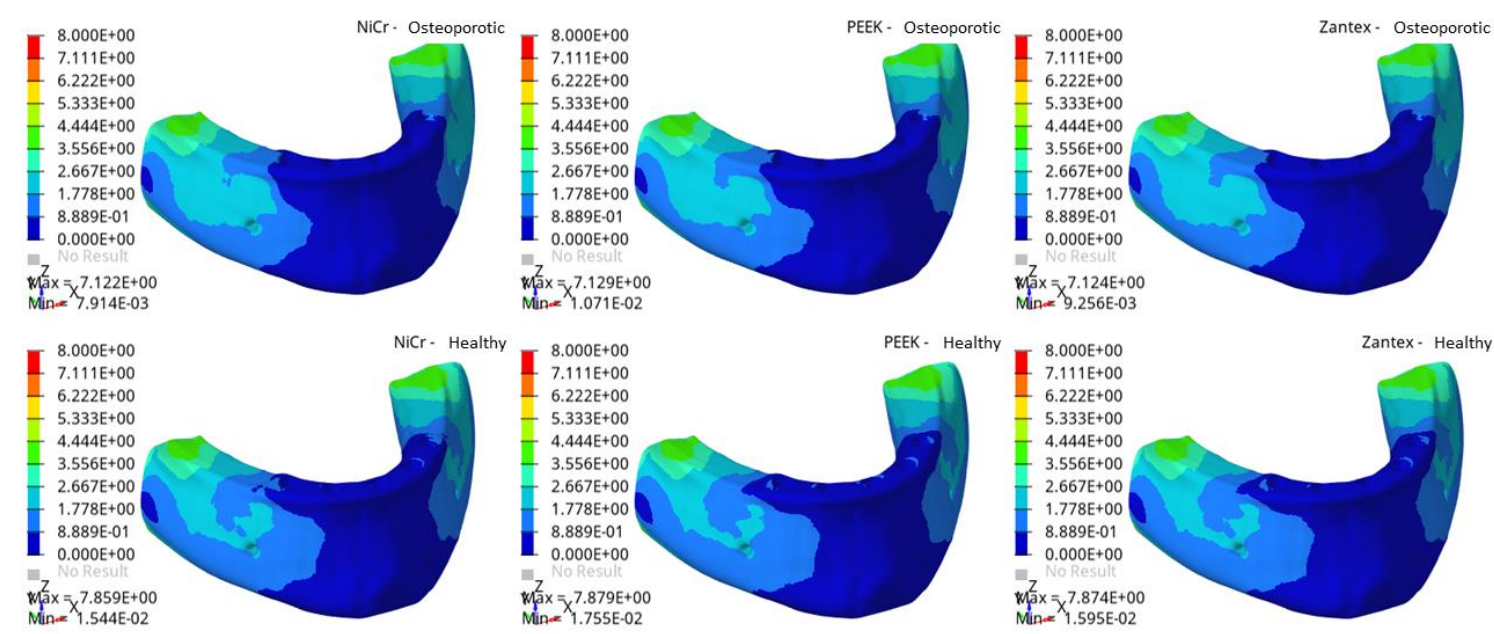

Source: Authors.

Table 1: Variation in minimum and maximum values of axial stress - cortical bone.

\begin{tabular}{|l|l|l|l|}
\hline Comparison [\%] & Ni-Cr & PEEK & Zantex \\
\hline Osteoporotic bone & $-48.74 \%$ to $-9.38 \%$ & $-30.63 \%$ to $-9.29 \%$ & $-40.05 \%$ to $-9.35 \%$ \\
\hline Normal bone & Reference & $13.67 \%$ to $0.25 \%$ & $3.30 \%$ to $0.19 \%$ \\
\hline
\end{tabular}

Source: Authors.

The medullary bone was subjected to larger axial loads and was more effective in dissipating these loads than the cortical bone. In comparison with the normal bone, the osteoporotic bone was subjected to larger loads; in the osteoporotic bone, $\mathrm{Ni}-\mathrm{Cr}$ performed worse than PEEK and Zantex in dissipating these loads (Figure 2 and Table 2).

Figure 2: Axial load medullary bone stress (Mpa).

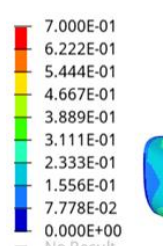

Max $x_{1.867 E-04}^{6.812 E-01}$

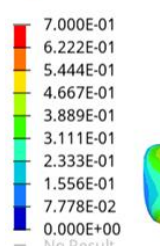

$\begin{aligned} & 7 \\ & \text { Max }\end{aligned}=x_{5.022 E-04}^{7.410 E-01}$
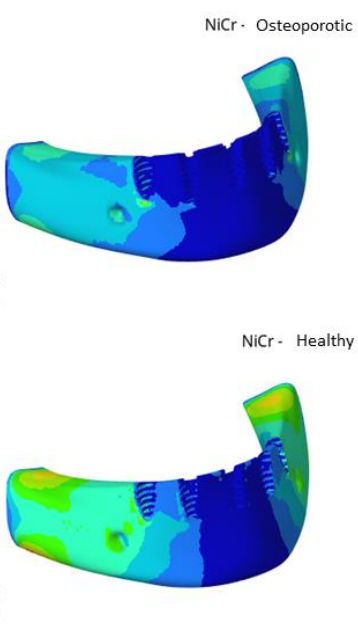

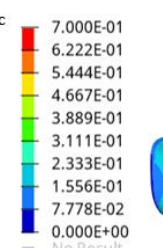

$\mathrm{Max}^{7}=x^{6.961 \mathrm{E}-01}$ Min $=2.252 \mathrm{E}-04$

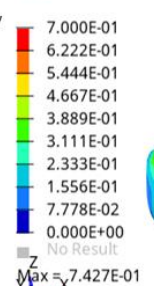

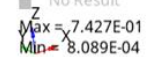
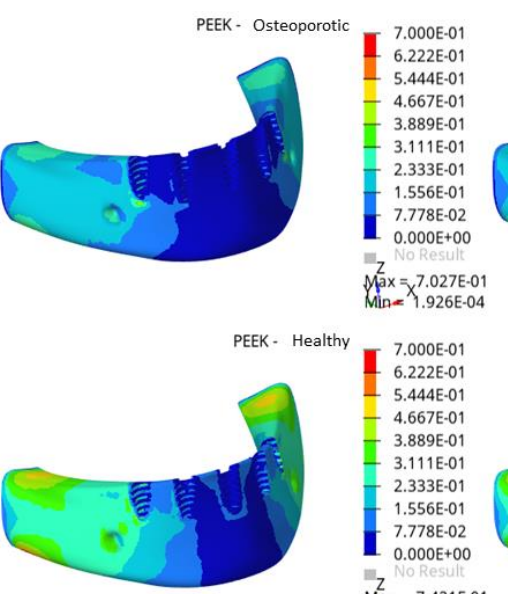

$\mathrm{Max}^{2}=\mathrm{x}^{7.421 \mathrm{E}-01}$

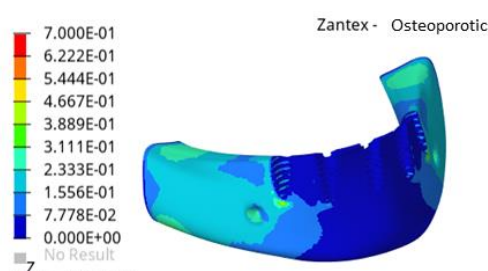

$\mathrm{Max}^{Z}=x^{7.027 E-01}$

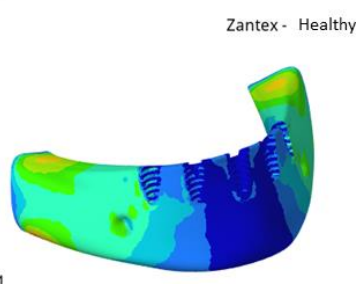

Source: Authors. 
Table 2: Variation of minimum and maximum values of axial stress - medullary boné.

\begin{tabular}{|l|l|l|l|}
\hline Comparison [\%] & Ni-Cr & PEEK & Zantex \\
\hline Osteoporotic bone & $-62.82 \%$ to $-8.07 \%$ & $-55.16 \%$ to $-6.06 \%$ & $-61.65 \%$ to $-5.17 \%$ \\
\hline Normal bone & Reference & $61.07 \%$ to $0.23 \%$ & $54.60 \%$ to $0.15 \%$ \\
\hline
\end{tabular}

Source: Authors.

$\mathrm{Ni}-\mathrm{Cr}$ bars were subjected to larger axial loads and presented larger maximum load values in the osteoporotic bone. Strain transmission to the Ni-Cr bar was more evidenced than in PEEK and Zantex bars. PEEK and Zantex show great effectiveness in absorbing strength and dissipating load to other structures. Stress was concentrated in the center of the bar, next to the midline for all models (Figure 3 and Table 3).

Figure 3: Axial load bar stress (Mpa).

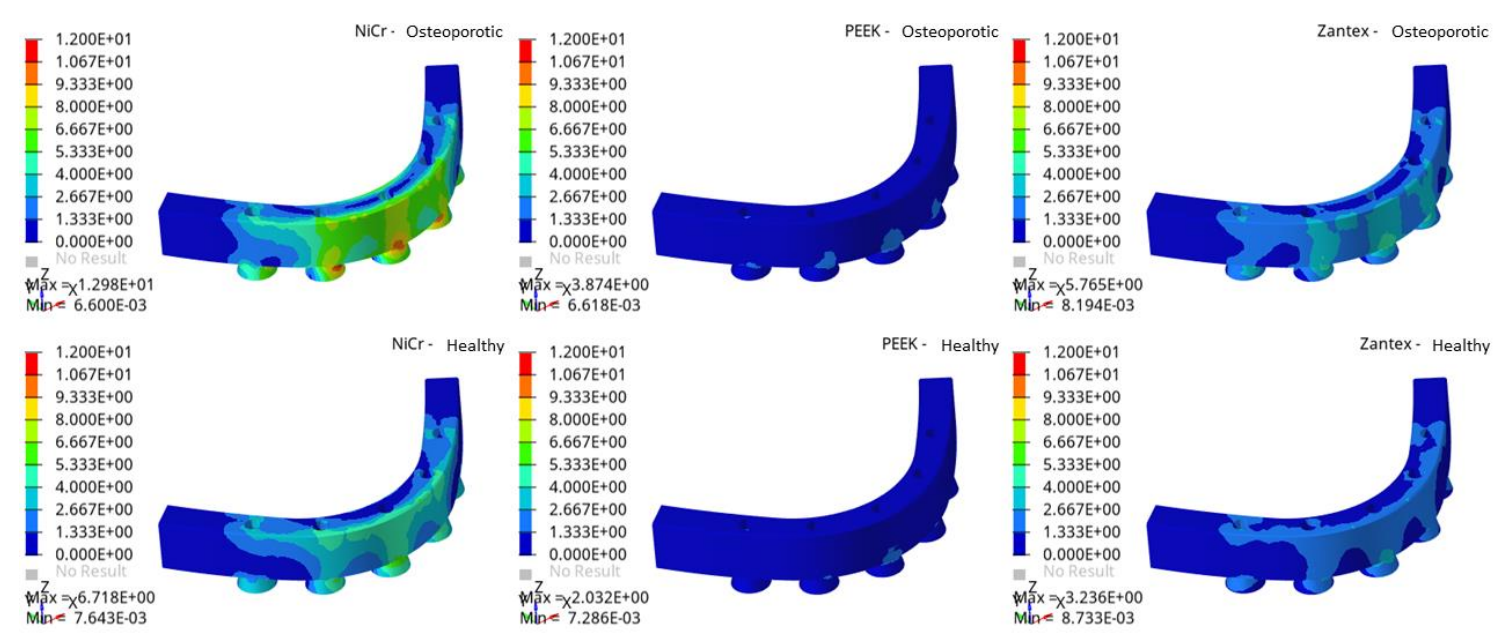

Source: Authors.

Table 3: Variation in minimum and maximum values of axial stress - bar.

\begin{tabular}{|l|l|l|l|}
\hline Comparison [\%] & Ni-Cr & PEEK & Zantex \\
\hline Osteoporotic bone & $-13.65 \%$ to $93.21 \%$ & $-13.41 \%$ to $-42.33 \%$ & $7.21 \%$ to $-14.19 \%$ \\
\hline Normal bone & Reference & $-4.67 \%$ to $-69.75 \%$ & $14.26 \%$ to $-51.83 \%$ \\
\hline
\end{tabular}

Source: Authors.

\section{Oblique loads}

Under oblique load, all three materials - Ni-Cr, PEEK and Zantex, presented similar behavior in the osteoporotic bone, and in the normal bone, PEEK and Zantex did not dissipate strength effectively, transmitting most of the load to the bone. In all models, the loads were concentrated on the buccal surface of the bone (Figure 4 and Table 4). 
Figure 4: Oblique load cortical bone stress (Mpa).

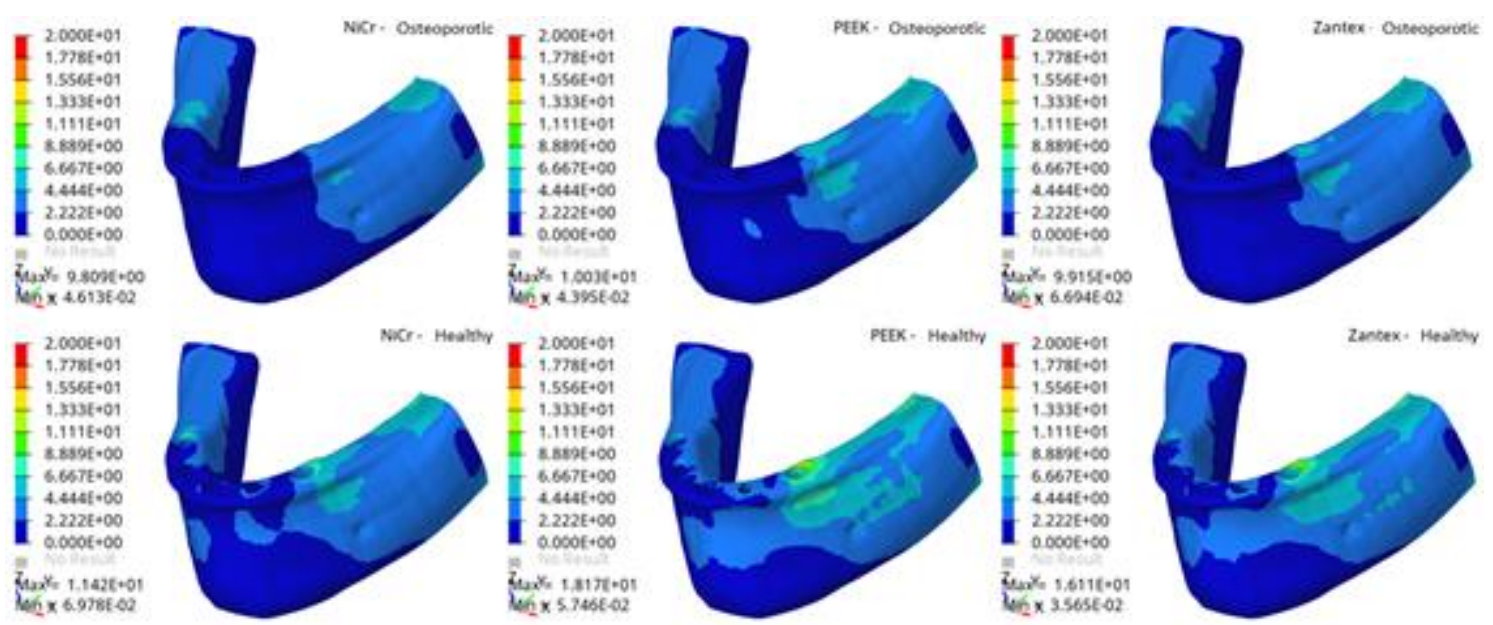

Source: Authors.

Table 4: Variation in minimum and maximum values of oblique stress - cortical bone.

\begin{tabular}{|l|l|l|l|}
\hline Comparison [\%] & Ni-Cr & PEEK & Zantex \\
\hline Osteoporotic bone & $-33.89 \%$ to $-14.11 \%$ & $-37.02 \%$ to $-12.17 \%$ & $-4.07 \%$ to $-13.18 \%$ \\
\hline Normal bone & Reference & $-17.66 \%$ to $59.11 \%$ & $-48.91 \%$ to $41.07 \%$ \\
\hline
\end{tabular}

Source: Authors.

All three material - Ni-Cr, PEEK and Zantex - performed better to dissipate loads in the medullary osteoporotic bone under oblique load. Variations between models were small and followed a similar pattern of load dissipation in both simulations (Figure 5 and Table 5).

Figure 5: Medullary bone oblique load stress (Mpa).
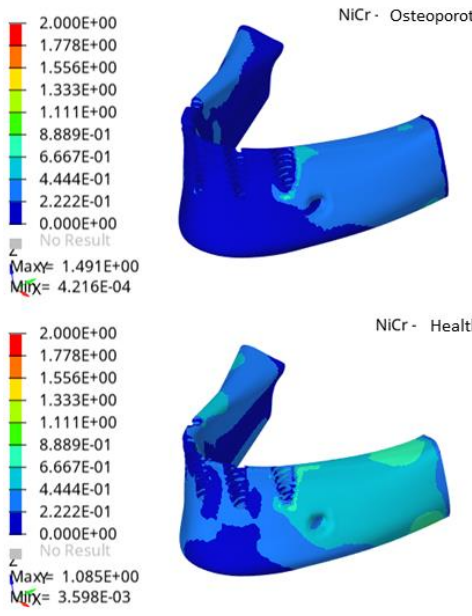
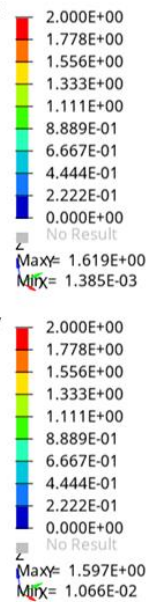
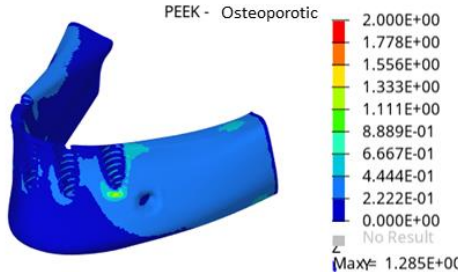

Maxy $=1.285 \mathrm{E}+00$
Mifx $=9.028 \mathrm{E}-04$
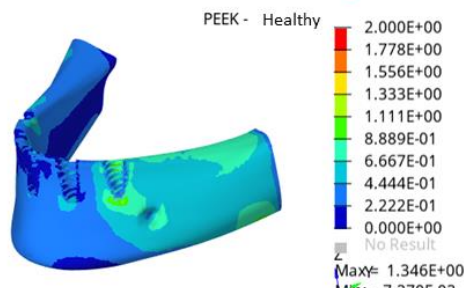

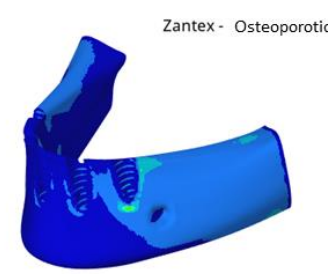

Zantex- Healthy

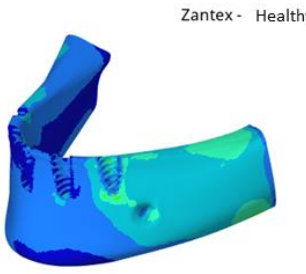

Source: Authors. 
Table 5: Variation in minimum and maximum values of oblique stress - medullary bone

\begin{tabular}{|l|l|l|l|}
\hline Comparison [\%] & Ni-Cr & PEEK & Zantex \\
\hline Osteoporotic bone & $-88.28 \%$ to $37.42 \%$ & $-61.51 \%$ to $49.22 \%$ & $-74.91 \%$ to $18.43 \%$ \\
\hline Normal bone & Reference & $196.28 \%$ to $47.19 \%$ & $104.84 \%$ to $24.06 \%$ \\
\hline
\end{tabular}

Source: Authors.

Ni-Cr showed poorer performance in comparison with PEEK and Zantex, transmitting more strength to the bar in all models. PEEK and Zantex showed better load dissipation, with the same pattern in both normal and osteoporotic bones (Figure 6 and Table 6).

Figure 6: Oblique load bar stress (Mpa).

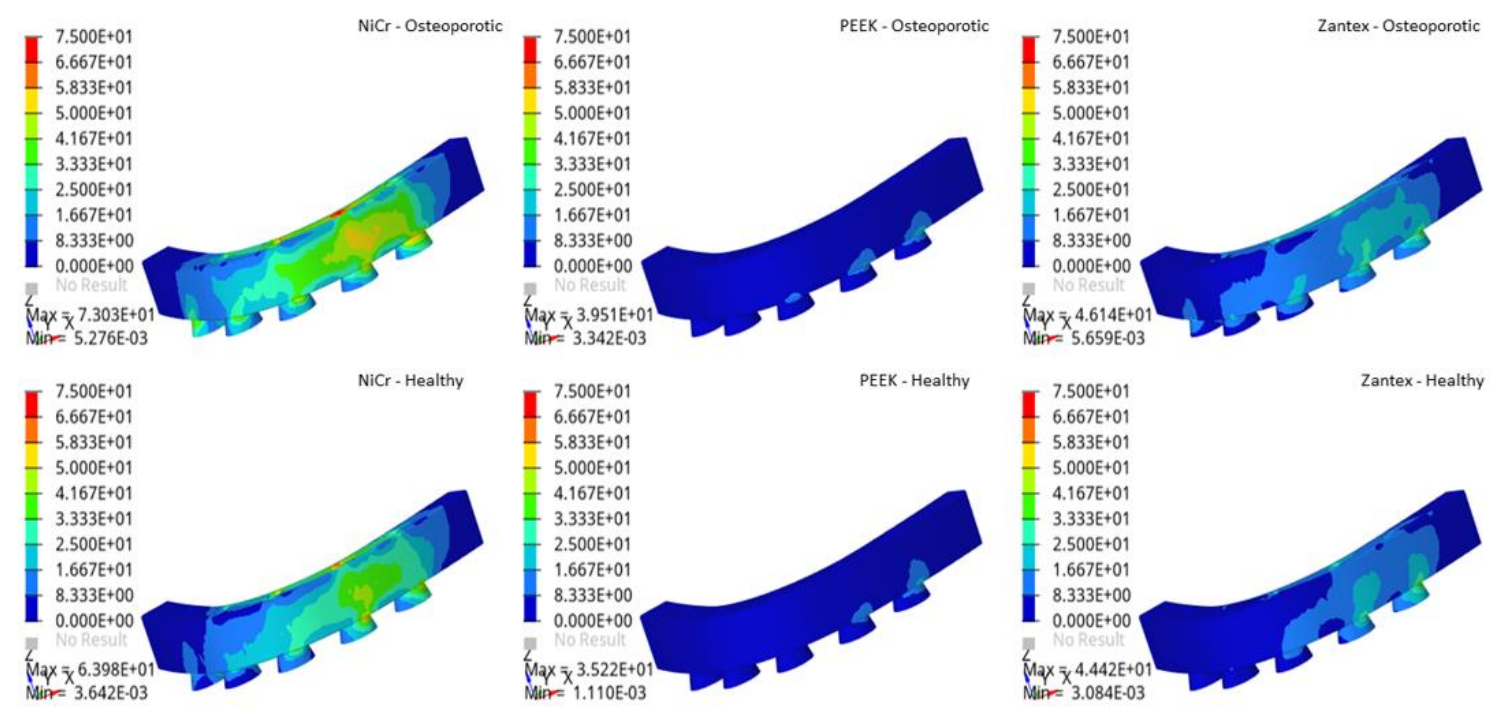

Source: Authors.

Table 6: Variation in minimum and maximum values of oblique stress - bar.

\begin{tabular}{|l|l|l|l|}
\hline Comparison [\%] & Ni-Cr & PEEK & Zantex \\
\hline Osteoporotic bone & $44.62 \%$ to $14.15 \%$ & $-8.24 \%$ to $-38.25 \%$ & $55.38 \%$ to $-27.88 \%$ \\
\hline Normal bone & Reference & $-69.52 \%$ to $-44.95 \%$ & $-15.32 \%$ to $-30.57 \%$ \\
\hline
\end{tabular}

Source: Authors.

\section{Discussion}

The osteoporotic bone is less dense (Kribbs, 1990). Hence, before the placement of the implants, it is key to assess the quality and quantity of the bone (Yeler et al., 2016). The volume reduction in the alveolar ridges of the upper and lower jaw may hinder rehabilitation with prostheses and implants depending on its severity (Chaim et al., 2016) since it can compromise the bone consolidation (Alghamdi \& Jansen, 2020; Geng et al., 2021). In the present study, results showed that the osteoporotic bone models are subjected to more stress than the normal bone models for all simulated structures. This may be caused by the lesser 
resistance, lesser density and hardness and smaller mass of the osteoporotic bone as found in real-life conditions (Kribbs, 1990; Helgason et al., 2008; Alghamdi \& Jansen, 2020). Thus, the bone is more affected by the strength applied on the bar, corroborating results found in other studies (Franco et al., 2017).

The largest peaks of load were found on the medullary bone, both in the normal and osteoporotic models, which was also more effective in dissipating strength than the cortical bone. This is due to the cortical bone's larger density and elasticity module (Kribbs, 1990; Helgason et al., 2008; Mattos et al., 2012); the medullary bone, being spongy and less compact and rigid (Mattos et al., 2012), allows a better load dissipation.

Polymers have been studied as a replacement for metal in protocol-type prostheses infrastructures because they are lighter and more aesthetic materials, among other factors (Anzolin et al., 2017; Aquino et al., 2018; Jaros et al., 2018). Polyether ether ketone (PEEK), previously used in Medicine in orthopedic prostheses and devices, has been employed in dentistry due to its good mechanical behavior (Carvalho et al., 2017; Aquino et al., 2018; Jaros et al., 2018) and elasticity module close to that of the jawbone (Bechir et al., 2016; Manolea et al., 2017). It has been noted that polymers reinforced with intertwined glass fibers show better fracture strength than those reinforced with unidirectional fibers (Vallittu,1998), thus justifying Zantex (Bono et al., 2016) as the polymer of choice for this study. This novel material, recently presented as an alternative for the bars manufacturing, has good fracture strength (Bergamo et al.,2019), resilience and flexibility similar to the bone's, good fatigue strength and dimensional stability. Effective properties of tensile, compression and flexural strength, and good adhesion to several materials are also mentioned by the manufacturer. Considering the lack of studies on Zantex, this study adds to the literature by providing knowledge on its use as protocol-type prostheses infrastructure.

In the present study, PEEK and Zantex bars generally presented good results since they seem to function as effective dissipators of strength, perfoming better than $\mathrm{Ni}-\mathrm{Cr}$ bars in normal and osteoporotic bones. Other studies have also shown that Ni-Cr bars normally show higher strength in the same load conditions (Anzolin et al., 2017; Jaros et al., 2018) given that they are more resistant to compression than PEEK bars (Carvalho et al., 2020).

Based on the experimental results shown here and on the theoretical background, further research is needed to safely assess the relationship between the material used in protocol-type prostheses infrastructures and the bone condition.

\section{Conclusion}

The largest load peaks were concentrated on the medullary bone, which was more effective in dissipating loads than the cortical bone, both in normal and osteoporotic conditions.

The osteoporotic bone was subjected to more stress than the normal bone in all simulated structures.

PEEK and Zantex bars were generally effective elements of strength dissipation, performing better than $\mathrm{Ni}-\mathrm{Cr}$ bars in both types of bones.

Here, the relevance of an assessment of the bone condition and its relation with the material used in the protocol-type prostheses infrastructure is confirmed.

\section{References}

Alghamdi, H. S. \& Jansen, J. A. (2020) The development and future of dental implants. Dental Materials Journal, 39(2), 167-172.

Anzolin, D., et al. (2017). Análise da resistência pelo método dos elementos finitos de barras de protocolo confeccionadas em PEEK reforçado por fibra de carbono. In: 34th SBPqO Annual Meeting, 2017, Campinas - SP. Brazilian Oral Research, 267.

Aquino, M. M. O., et al. (2018) Cantilever Protocol Bars in Acrylated Polyetheretherketone (Peek): A Mechanical Compression Assay. OHDM - Oral Health and Dental Management, 17,1022.

Bechir, E. S., el al. (2016). The Advantages of BioHPP Polymer as Superstructure Material in Oral Implantology. Materiale Plastice, 53(3), 394-98. 
Research, Society and Development, v. 11, n. 2, e59111226183, 2022

Bergamo, E., et al. (2019) Confiabilidade e modo de falha de próteses parciais fixas implantossuportadas com infraestrutura de compósito reforçado por fibra. PróteseNews, 2019(6), 672-680.

Bonon, A. J., et al. (2016). Physicochemical characterization of three fiber-reinforced epoxide-based composites for dental applications. Materials Science and Engineering, 69, 905-913.

Campbell, S. D., et al. (2017). Removable partial dentures: The clinical need for innovation. J Prosthet Dent., 118(3), 273-80.

Carvalho, G. A., et al. (2017). Polyether ether ketone in protocol bars: Mechanical behavior of three designs. J Int Oral Health, 9(5), 202-206.

Chaim, A., el al. (2016). Alterações no complexo maxilo-mandibular na osteoporose: revisão de literatura. Revista Uningá, 49, 79-84

Craig, R. G. (1985). Restorative Dental Materials. (7a.ed.), Mosby.

Franco, A. B., et al. (2017). Osteoporosis and endodontic access: Analysis of fracture using finite element method. IJODM, 16,1-5.

Geng, Z., et al. (2021). Nano-needle strontium-substituted apatite coating enhances osteoporotic osseointegration through promoting osteogenesis and inhibiting osteoclastogenesis. Bioactive Materials, 6, 905-915

Helgason, B., et al. (2008). Mathematical relationships between bone density and mechanical properties: a literature review. Clin Biomechanics, 23(2), 135-46.

Jaros, O. A. L., et al. (2018). Biomechanical behavior of an implant system using polyether ether ketone bar: Finite element analysis. J Int Soc Prevent Communit Dent, 8, 446-50.

Kribbs, P. J. (1990). Comparison of mandibular bone in normal and osteoporotic women. University of Washington, 63, 219-22.

Leekholm, U., et al. (1998). Surgical considerations and possible shortcomings of host sites. J Prosthet Dent, 79(1),43-8.

Manolea, H. O., et al. (2017). Current Options of Making Implant Supported Prosthetic Restorations to Mitigate the Impact of Occlusal Forces. Defect and Diffusion Forum, 376, 66-77.

Mattos, C. M. A., et al. (2012) Numerical analysis of the biomechanical behaviour of a weakened root after adhesive reconstruction and post-core rehabilitation. J Dent. 40(5), 423-32.

Najeeb, S., et al. (2015). Nanomodified peek dental implants: Bioactive composites and surface modification - A review. Int J Dent, 2015,1 , 7.

Rodrigues, J. T., et al. (2014). Avaliação de pacientes odontológicos para auxílio no diagnóstico precoce da osteoporose. Rev Bras Odontol, 71(2), 211-5. Schwitalla, A. D., et al. Finite element analysis of the biomechanical effects of PEEK dental implants on the peri-implant bone. J Biomechanics, 48(1),1-7.

Vallittu, P. K. (1998). The effect of glass fiber reinforcement on the racture resistance of a provisional fixed partial denture. J. Prosthet. Dent, 79(2), 125-129.

Yeler, D. Y., et al. (2016). Bone quality and quantity measurement techniques in dentistry. Cumhuriyet. 19(1), 73-86. 